Email: jkesislam@unisma.ac.id

Home Page : http://riset.unisma.ac.id/index.php/jki

\title{
Efek Pemberian Minyak Atsiri Daun Sirsak (Annona muricata Linn) terhadap Penurunan Kadar Tumor Necrosis Factor Alpha (TNF- $\alpha$ ) Hepar Tikus Wistar Jantan yang Diinduksi Rifampisin
}

\author{
Shofiyyatunnisa' Wuslatush Sholihah*, Marindra Firmansyah**, Dini Sri Damayanti** \\ *Mahasiswa Program Studi Pendidikan Dokter, Fakultas Kedokteran Universitas Malang \\ ** Staf Pengajar Program Studi Pendidikan Dokter, Fakultas Kedokteran Universitas Malang \\ E-mail: shofiyyatunnisa3003@gmail.com
}

\begin{abstract}
Abstrak
Pendahuluan: Rifampisin merupakan salah satu obat anti tuberkulosis yang dilaporkan memiliki efek hepatotoksik melalui peningkatan ROS (Reactive Oxigen Species) sehingga memicu nekrosis sel hepar dan merangsang pembentukan TNF- $\alpha$. Minyak atsiri daun sirsak (Annona muricata Linn.) memiliki kandungan linalool, $\beta$-caryophyllen, trans-caryophyllen, germacrene $A$, germacrene $B$, germacrene $D$, sesquisterpene, $\beta$ canidine, $\gamma$-canidine. Tujuan penelitian ini adalah membuktikan efek minyak atsiri daun sirsak (Annona muricata Linn.) terhadap kadar Tumor Necrosis Factor Alpha (TNF- $\alpha$ ) hepar tikus wistar jantan yang diinduksi rifampisin.
\end{abstract}

Metode: Penelitian eksperimental laboratorium dengan desain control group post test only secara in vivo menggunakan 25 tikus wistar jantan dan terbagi menjadi 5 kelompok, yaitu kelompok KN (minyak jagung), KP (Rifampisin), P1 (Rifampisin + Minyak atsiri 1,5\%), P2 (Rifampisin + Minyak atsiri 3\%), P3 (Rifampisin + Minyak atsiri 6\%). Penelitian dilakukan selama 6 minggu kemudian dilanjutkan dengan pemeriksaan kadar TNF- $\alpha$. Analisa data menggunakan uji One Way ANOVA yang dilanjutkan dengan post hoc test menggunakan Least Significant Difference (LSD). Hasil dikatakan bermakna jika $\mathrm{p}<0,05$.

Hasil: Induksi rifampisin dapat meningkatkan kadar TNF- $\alpha$ hepar dibandingkan dengan kelompok KN ( $<<0,05)$. Pemberian minyak atsiri daun sirsak (Annona muricata Linn.) pada P1, P2, P3 mampu menurunkan kadar TNF- $\alpha$ hepar $(\mathrm{p}<0,05)$ dibandingkan dengan kelompok KP. Hasil yang diperoleh diduga disebabkan bahan aktif yang terkandung dalam minyak atsiri yang berperan sebagai antioksidan dan antiinflamasi.

Kesimpulan: Minyak atsiri daun sirsak (Annona muricata Linn.) pada semua dosis dapat menurunkan kadar TNF- $\alpha$ hepar tikus wistar jantan yang diinduksi rifampisin.

Kata kunci: rifampisin, minyak atsiri daun sirsak (Annona muricata Linn.), TNF- $\alpha$ hepar

\section{Effect of Essential Oil of Annona muricata Linn. on Decreased Levels of Tumor Necrosis Factor Alpha (TNF- $\alpha$ ) Liver in Male Wistar Rats which Induced by Rifampicin}

\begin{abstract}
Introduction: Rifampicin is one of anti-tuberculosis drugs are reported to have hepatotoxic effects through increasing ROS (Reactive Oxygen Species) so that triggering necrosis of liver cells and stimulates the formation of TNF- $\alpha$. Essential oil of Annona muricata Linn. contains linalool, $\beta$-caryophyllen, trans-caryophyllen, germacrene A, germacrene $B$, germacrene $D$, sesquisterpene, $\beta$-canidine, $\gamma$-canidine. The objective of this study is to investigate the effect of essential oil of Annona muricata Linn. on levels of Tumor Necrosis Alpha (TNF- $\alpha$ ) liver in male wistar rats which induced by rifampicin.

Methods: This was an invivo experimental study with control group post test only design and use 25 male wistar rats and divided into 5 groups, they are KN (corn oil), KP (Rifampicin), P1 (Rifampicin + Essential oil 1,5\%), P2 (Rifampisin + Essential oil 3\%), P3 (Rifampisin + Essential oil 6\%) for 6 weeks and then levels of TNF- $\alpha$ liver will be checked. Analysis of the data using One Way (ANOVA) test and then tested by post hoc test using Least Significant Difference (LSD). The result significant if $\mathrm{p}<0,05$.

Result: Induced rifampicin can increased levels of TNF- $\alpha$ liver than group $\mathrm{KN}(\mathrm{p}<0,05)$. Treatment of essential oil of Annona muricata Linn. on P1, P2, and P3 can reduced levels of TNF- $\alpha$ liver than group KP (p<0,05). Allegedly this is due to the active ingredient in the essential oils act as antioxidants and antiinflammatory.

Conclusion: Essential oil of Annona muricata Linn. at all doses can reduced levels of TNF- $\alpha$ liver in male wistar rats which induced by rifampicin.
\end{abstract}

Keywords: rifampicin, essential oil of Annona muricata Linn., TNF- $\alpha$ liver 


\section{PENDAHULUAN}

Rifampisin merupakan salah satu OAT (Obat Anti Tuberculosis) lini pertama. Penggunaan dalam jangka waktu lama dapat meningkatkan potensi terjadinya kerusakan hepar ${ }^{1}$. Sejumlah 16 orang dari 500.000 pasien yang mendapat terapi rifampisin dilaporkan meninggal akibat hepatotoksisitas ${ }^{2}$. Rifampisin dapat menginduksi hepatotoksik melalui peningkatan radikal bebas akibat metabolisme pada hepar yang menggunakan enzim sitokrom P-450. Peningkatan radikal bebas akan memicu nekrosis sel hepar dan merangsang pembentukan TNF- $\alpha^{3}$. Sehingga rifampisin digunakan sebagai induksi hepatotoksik pada penelitian ini. TNF- $\alpha$ merupakan sitokin utama pada respon inflamasi akut. Infeksi yang berat dapat memicu produksi TNF- $\alpha$ dalam jumlah besar yang menimbulkan reaksi sistemik ${ }^{4}$.

Untuk mengurangi reaksi hepatotoksik dari obat, tubuh membutuhkan antioksidan sebagai hepatoprotektor. Salah satu antioksidan yang dapat mengurangi efek hepatotoksik adalah tanaman sirsak (Annona muricata Linn.) $)^{5}$. Tanaman sirsak (Annona muricata Linn.) merupakan tanaman dari family annonacea yang banyak tumbuh di sekitar masyarakat Indonesia. Salah satu bagian tanaman sirsak yang dapat dimanfaatkan sebagai hepatoprotektor adalah daun sirsak. Beberapa penelitian menyatakan bahwa daun sirsak memiliki aktivitas antioksidan yang mampu menghambat dan mencegah kerusakan oksidatif hepar ${ }^{6}$.

Senyawa kimia yang terkandung dalam daun sirsak antara lain: flavonoid, alkaloid, tanin, saponin, dan minyak atsiri ${ }^{6}$. Berdasarkan penelitian Nahdhiyah (2012), kandungan kimia daun sirsak didapatkan dari rebusan dimana hasil zat kimianya bersifat larut air ${ }^{7}$. Hal ini menimbulkan pertanyaan bagi peneliti untuk meneliti lebih lanjut mengenai kandungan kimia daun sirsak yang tidak larut air, yaitu minyak atsiri. Minyak atsiri daun sirsak dapat dihasilkan menggunakan metode destilasi. Analisa gas chromatography - mass spectrometry (GC-MS) pada penelitian pendahuluan yang dilakukan pada penelitian ini menunjukkan kandungan minyak atsiri daun sirsak (Annona muricata Linn.) antara lain linalool, $\beta$-caryophyllen, trans-caryophyllen, germacrene A, germacrene $B$, germacrene $D$, sesquisterpene, $\beta$-canidine, $\gamma$ canidine $^{8}$.

Data yang menyatakan bahwa minyak atsiri daun sirsak (Annona muricata Linn.) juga memiliki efek sebagai hepatoprotektor belum ada. Oleh karena itu, peneliti ingin membuktikan efek pemberian minyak atsiri daun sirsak (Annona muricata Linn.) terhadap penurunan kadar TNF- $\alpha$ hepar tikus wistar jantan yang diinduksi rifampisin.

\section{METODE PENELITIAN}

\section{Rancangan Penelitian}

Penelitian dilaksanakan secara true eksperimental laboratorium ini menggunakan desain penelitian control group post test only secara in vivo menggunakan hewan coba tikus wistar jantan yang diberi perlakuan dengan induksi rifampisin dosis terapi $(10 \mathrm{mg} / \mathrm{KgBB})^{1,9}$. Penelitian dilakukan selama 6 minggu yang mengacu pada penelitian oleh Nahdhiyah (2012) dan telah dilakukan penelitian penahuluan ${ }^{7}$. Dosis minyak atsiri daun sirsak merupakan dosis eksplorasi. Penelitian ini dilaksanakan di Laboratorium Faal Fakultas Kedokteran Universitas Brawijaya, Laboratorium Putra Indonesia, dan Laboratorium Kimia Fakultas Kedokteran Unisma bulan Februari - April 2016. Penelitian ini telah mendapatkan ethical clearance dari Universitas Brawijaya dengan nomor sertifikat No.03/EC/KEPK/01/2016.

\section{Prosedur Penelitian}

Penelitian menggunakan hewan coba tikus wistar putih (Rattus novergicus) dengan kriteria inklusi berjenis kelamin jantan, berusia sekitar 12 minggu, dengan kisaran berat badan 150-200 gram, dengan kriteria kondisi sehat. Tikus yang sehat mempunyai ciri-ciri bulu yang bersih dan mengkilat, mata jernih bersinar, nafsu makan yang baik dan berat badan bertambah setiap hari. Tikus wistar jantan dipilih karena tidak adanya pengaruh siklus hormonal estrogen yang menyebabkan efek bias dari hasil penelitian ${ }^{7}$.

Sampel yang digunakan sebanyak 25 ekor tikus wistar jantan yang dibagi dalam 5 kelompok yang dilakukan secara acak (random sampling), yaitu kelompok Kontrol negatif (KN) diinduksi minyak jagung, Kontrol positif (KP) diinduksi rifampisin, Perlakuan 1 (P1) diinduksi rifampisin + minyak atsiri $1,5 \%$, Perlakuan $2(\mathrm{P} 2)$ diinduksi rifampisin + minyak atsiri 3\%, dan Perlakuan 3 (P3) diinduksi rifampisin + minyak atsiri $6 \%$. Sebelumnya tikus diadaptasi terlebih dahulu selama 7 hari dalam kandang yang berisi 2 ekor tikus tiap kandang .

\section{Pembuatan dan Induksi Rifampisin}

Rifampisin yang digunakan adalah dosis terapi $(10 \mathrm{mg} / \mathrm{KgBB} / \mathrm{hari})^{1}$. Dosis dikonversikan sesuai berat badan tikus menjadi 2 mg/ekor. Kemudian, dihaluskan dan dilarutkan dengan minyak jagung sampai $1 \mathrm{ml}$. Induksi rifampisin 
ini diberikan setiap hari pada kelompok KP, P1, P2, dan P3 secara personde lambung selama 6 minggu ${ }^{7}$.

\section{Pembuatan Minyak Atsiri Daun Sirsak (Annona muricata Linn.)}

Pembuatan minyak atsiri daun sirsak menggunakan metode destilasi uap air. Simplisia daun sirsak didapat dari Balai Materia Medika Batu dengan nomor surat 074/71/101.8/2016. Simplisia daun sirsak yang didapat diiris-iris dan dimasukkan ke dalam ketel alat destilasi. Ketel suling dirangkai dengan pendingin (kondensor). Ketel uap kemudian dipanaskan hingga tekanan 1 atm. Uap yang dihasilkan disalurkan melalui selang yang sedah terhubung dengan ketel suling. Air dialirkan pada kondensor dan dijaga agar air terus mengalir, sehingga minyak yang menguap semuanya terembunkan dan tidak lepas ke udara. Hasil destilasi adalah minyak atsiri yang belum murni. Destilat yang diperoleh merupakan campuran minyak dengan air yang selanjutnya dipisahkan dalam corong pisah. Setelah terpisah, destilat di tambahkan Nheksana sebagai pengikat minyak. Kemudian, dievaporasi pada suhu $45^{\circ} \mathrm{C}$ untuk menguapkan $\mathrm{N}$-heksana. Hasilnya adalah minyak atsiri murni.

\section{Pembuatan Suspensi Minyak Atsiri Daun Sirsak (Annona muricata Linn.)}

Minyak atsiri daun sirsak dengan konsentrasi $1,5 \%, 3 \%$, dan $6 \%$ diperoleh dari rumus $\mathrm{V}_{1} \mathrm{M}_{1}=\mathrm{V}_{2} \mathrm{M}_{2}{ }^{10}$. Hasil yang didapatkan kemudian dilarutkan dalam minyak jagung hingga $1 \mathrm{ml}$.

Pemberian minyak atsiri daun sirsak $1,5 \%$, $3 \%$, dan 6\% dilakukan secara personde kepada kelompok P1, P2, dan P3 pada 2 jam setelah diinduksi rifampisin.

\section{Pengambilan Sample Hewan Coba}

Pembedahan hewan coba diawali dengan cara tikus diinjeksi ketalar $(50 \mathrm{mg} / \mathrm{kgBB})$, kemudian tikus dibedah secara vertikal mengikuti linea mediana dari abdomen menuju ke thorak dengan gunting sampai seluruhnya terbuka. Kemudian, diambil organ hepar dan diletakkan dalam tabung atau wadah untuk dilakukan proses pemeriksaan selanjutnya. Tikus yang telah di sacrifice (dikobankan) akan dilakukan proses penguburan.

\section{Pemeriksaan Kadar TNF- $\alpha$ Hepar}

Jaringan hepar ditimbang 1 gram kemudian dicuci dengan PBS, digerus sampai halus lalu ditambahkan cairan PMSF $1 \mathrm{ml}$. Setelah itu diinkubasi selama 30 menit pada suhu $40^{\circ} \mathrm{C}$ kemudian disentrifuge dengan kecepatan 2000 rpm selama 20 menit. Setelah disentrifuge diambil supernatannya yang sebelumnya dilarutkan dahulu dengan coating buffer dengan perbandingan 1:20, selanjutnya diinkubasi dengan suhu $4^{\circ} \mathrm{C}$ selama semalam. Setelah diinkubasi, dicuci sebanyak 3 kali menggunakan PBS-T 0,2\% masing-masing selama 3 menit. Kemudian blocking dengan BSA $1 \%$ selama 30 menit. Setelah 30 menit, dicuci kembali sebanyak 3 kali menggunakan PBS-T 0,2 \% masing-masing selama 3 menit kemudian tambahkan antibodi primer 1:500 dalam PBS dan diinkubasi selama 1 jam. Lalu dicuci kembali menggunakan PBS-T 0,2\% sebanyak 3 kali masing-masing 3 menit kemudian tambahkan dengan antibodi sekunder IgG Biotin Anti Mouse 1:1000 dan diinkubasi selama 1 jam. Setelah diinkubasi, dicuci kembali sebanyak 3 kali menggunakan PBS-T 0,2\% masing-masing selama 3 menit kemudian tambahkan dengan SA-HRP 1:1000 dan diinkubasi selama 1 jam. Setelah 1 jam, dicuci kembali sebanyak 3 kali menggunakan PBS-T 0,2\% masing-masing selama 3 menit kemudian tambahkan sureblue TMB dan diinkubasi selama 30 menit. Lalu reaksi dihentikan menggunakan $\mathrm{HCl} 1 \mathrm{~N}$ dan diinkubasi selama 15 menit. Pada tahap selanjutnya, dilakukan pembacaan data dengan ELISA reader pada panjang gelombang $450 \mathrm{~nm}^{11}$.

\section{Teknik Analisa Data}

Data yang diiperoleh dilakukan uji normalitas dan homogenitas. Setelah terdistribusi normal, data dianalisis dengan mengggunakan metode uji One Way ANOVA (Analysis Of Varians) untuk menguji hipotesis yang ada. Bila ada perbedaan yang bermakna, dilanjutkan dengan post hoc test menggunakan Least Significant Difference (LSD) untuk mengetahui perbedaan antar perlakuan. Hasil dikatakan bermakna bila $\mathrm{p}<0,05$. Uji statistik menggunakan program SPSS versi 21 secara komputerisasi.

\section{HASIL PENELITIAN}

Tabel 1. Rerata Efek Pemberian Minyak Atsiri Daun Sirsak (Annona muricata Linn.) terhadap kadar TNFa Hepar Tikus Wistar Jantan yang Diinduksi Rifampisin

\begin{tabular}{cccc}
\hline No & Perlakuan & N & $\begin{array}{c}\text { Mean } \pm \text { SD } \\
(\mathbf{p g} / \mathbf{m l})\end{array}$ \\
\hline 1. & KN & 5 & $29.75 \pm 16.17^{\mathrm{a}}$ \\
2. & KP & 5 & $106 \pm 47.40^{\mathrm{b}}$ \\
\hline
\end{tabular}




\begin{tabular}{llll}
\hline 3. & P1 & 5 & $85.5 \pm 42.19^{\mathrm{c}}$ \\
4. & P2 & 5 & $47 \pm 21.01^{\mathrm{d}}$ \\
5. & P3 & 5 & $50 \pm 22,36^{\mathrm{e}}$
\end{tabular}

Keterangan :

* Notasi yang berbeda menunjukkan signifikan

Dari tabel 1 dapat dilihat bahwa hasil rerata kadar TNF- $\alpha$ hepar tikus wistar pada kelompok KP meningkat secara signifikan sebesar 356\% dibandingkan dengan kelompok $\mathrm{KN}$ dengan $\mathrm{p}<0,05$. Pemberian minyak atsiri daun sirsak (Annona muricata Linn.) pada kelompok P1, P2, dan P3 menunjukkan penurunan kadar TNF$\alpha$ yang signifikan $(p<0,05)$ secara berturut-turut sebesar 19\%, 56\%, dan 53\% dibandingkan dengan kelompok KP. Pemberian minyak atsiri daun sirsak (Annona muricata Linn.) pada antar kelompok P1, P2, dan P3 terjadi perbedaan yang signifikan. Pada kelompok P2 terjadi penurunan yang signifikan $(\mathrm{p}<0,05)$ sebesar $45 \%$ dibandingkan dengan kelompok P1. Pada kelompok P3 terjadi penurunan yang signifikan $(\mathrm{p}<0,05)$ sebesar $41 \%$ dibandingkan dengan kelompok P1 tetapi pada kelompok P3 terjadi peningkatan yang signifikan $(\mathrm{p}<0,05)$ sebesar $6 \%$ dibandingkan dengan kelompok P2.

\section{PEMBAHASAN}

\section{Efek Induksi Rifampisin terhadap Kadar TNF- $\alpha$ Hepar}

Pemberian rifampisin terhadap kadar TNF- $\alpha$ hepar menunjukkan bahwa kadar TNF- $\alpha$ hepar pada kelompok kontrol positif mengalami peningkatan yang signifikan $(\mathrm{p}<0,05)$ dibandingkan dengan kelompok kontrol negatif. Hal ini membuktikan bahwa paparan rifampisin dengan dosis $10 \mathrm{mg} / \mathrm{kgBB}$ dapat menyebabkan kerusakan hepar. Hal tersebut sejalan dengan penelitian yang dilakukan oleh Jannah (2016) yang menyebutkan bahwa rifampisin dengan dosis $10 \quad \mathrm{mg} / \mathrm{kgBB}$ selama 6 minggu menyebabkan peningkatan jumlah nekrosis sel hepatosit pada zona I, II, dan III ${ }^{12}$.

Kerusakan hepar akibat rifampisin ini sesuai dengan penelitian Chen (2006) bahwa pemberian rifampisin dapat menyebabkan hepatotoksik melalui peningkatan proses disfungsi protein, peroksidasi lipid, dan kerusakan DNA yang akan menyebabkan kematian sel baik secara apoptosis maupun nekrosis pada sel hepar ${ }^{13}$.

Pemberian rifampisin dapat menyebabkan kerusakan hepar dengan menginduksi enzim sitokrom P-450. Rifampisin masuk ke dalam tubuh melalui traktus gastrointestinal, diabsorbsi di dalam intestinal dan didistribusikan ke hepar untuk dimetabolisme dengan bantuan enzim P450. Rifampisin dimetabolisme oleh hepar dengan bantuan $\mathrm{O}_{2}$ dan sebagai kofaktor NADPH yang dapat menghasilkan radikal bebas superoxide $\left(\mathrm{O}_{2}^{-}\right)$. Peningkatan metabolisme oksidatif oleh karena induksi rifampisin akan meningkatkan terbentuknya radikal bebas. Radikal superoksida yang terbentuk akan dikatalis oleh antioksidan enzimatik (SOD) menjadi hidrogen peroksida dan air. Jika hidrogen peroksida mengalami reaksi fenton maka akan terbentuk radikal hidroksil ${ }^{14}$ sehingga akan menginduksi terjadinya stress oksidatif sel hepar. Peningkatan radikal bebas akan menyebabkan peroksidasi lipid, fragmentasi DNA dan fragmentasi protein $\operatorname{sel}^{3}$. Peroksidasi membrane lipid dapat menyebabkan hilangnya homeostasis $\mathrm{Ca}^{2+}$ sehingga terjadi masuknya kalsium ekstraseluler dan pengeluaran kalsium cadangan intraseluler (sisa mitokondria dan RE) ke dalam sitosol. Peningkatan $\mathrm{Ca}^{2+}$ sitosol mengaktifkan enzim fosfolipase A2 yang menyebabkan pemecahan fosfolipid mengakibatkan destruksi fosfolipid yang akan menstimulasi terjadinya nekrosis hepar ${ }^{15}$. Nekrosis sel tersebut akan mengeluarkan protein-protein yang dianggap asing oleh tubuh sehingga akan merangsang respon imun (aktifasi sel kuffer), sehingga mengaktifkan jalur intraseluler, mengaktifkan NF- $k \beta$ untuk proses transkripsi sitokin TNF- $\alpha$, IL-6, VCAM-1 sehingga terjadi respon inflamasi ${ }^{16}$. Jadi berdasarkan hal diatas, diduga bahwa TNF- $\alpha$ hepar tikus kelompok kontrol positif (induksi rifampisin) meningkat karena terjadi kerusakan pada hepar oleh efek radikal bebas sehingga terjadi peningkatan mediatormeditor inflamasi yaitu TNF- $\alpha$.

Efek Pemberian Minyak Atsiri Daun Sirsak (Annona muricata Linn.) terhadap Kadar TNF-a Hepar pada Tikus Wistar Jantan yang Diinduksi Rifampisin

Hasil penelitian menunjukkan penurunan kadar TNF- $\alpha$ hepar tikus wistar yang berbeda signifikan $(\mathrm{p}<0.05)$ pada kelompok perlakuan minyak atsiri dengan dosis $1,5 \%, 3 \%$, dan $6 \%$ secara berturut-turut sebesar 19\%, 56\%, dan $53 \%$ dibandingkan dengan kelompok kontrol positif. Hal ini menjelaskan bahwa pemberian minyak atsiri daun sirsak berpengaruh terhadap penurunan kadar TNF- $\alpha$ hepar tikus wistar setelah diinduksi rifampisin selama 6 minggu.

Mekanisme penurunan kadar TNF- $\alpha$ akibat pemberian minyak atsiri daun sirsak (Annona muricata Linn.) diduga melalui aktifitasnya 
sebagai antioksidan dan antiinflamasi. Hal ini sesuai dengan penelitian yang dilakukan oleh Miguel (2010) yang mengemukakan bahwa minyak atsiri daun sirsak memiliki aktifitas antioksidan dan antiinflamasi ${ }^{17}$. Senyawa terpenoid yang merupakan komposisi terbesar dalam minyak atsiri diduga bertanggungjawab dalam proses tersebut. Analisa GC-MS pada penelitian pendahuluan yang dilakukan pada penelitian ini menunjukkan kandungan yang terdapat dalam minyak atsiri daun sirsak (Annona muricata Linn.), antara lain linalool, $\beta$ caryophyllen, trans-caryophyllen, germacrene $A$, germacrene $B$, germacrene $D$, sesquisterpene, $\beta$-canidene, $\gamma$-canidene ${ }^{8}$. Hasil penelitian yang dilakukan oleh Damayanti (2016) yang mengukur aktivitas antioksidan minyak atsiri daun sirsak (Annona muricata Linn.) menggunakan metode 2,2 diphenyl-1picrylhydrazil (DPPH) didapatkan hasil penghambatan radikal 50\% $\left(\mathrm{IC}_{50}\right)$ sebesar $318,45 \mathrm{ppm}^{8}$. Hal ini menunjukkan adanya potensi antioksidan yang terkandung dalam minyak atsiri daun sirsak (Annona muricata Linn.) yang mana mekanisme kerjanya diduga melalui cara menghambat peroksidasi lipid dan scavenging hydroxyl radical ${ }^{8}$.

Kandungan minyak atsiri sebagai antiinflamasi dengan mekanisme penghambatan lipooksigenase dan penghambatan faktor proinflamasi TNF- $\alpha$. Senyawa $\beta$-caryophyllene, trans-caryophyllene, $\alpha$-pinene bertindak sebagai antiinflamasi melalui jalur 5lipooksigenase inhibitor. Senyawa lain bertindak sebagai antiinflamasi melalui jalur inhibitor pro-inflamasi IL-1 yaitu caryophyllene oxide. Sedangkan jalur inhibitor pro-inflamasi TNF- $\alpha$ dilakukan oleh senyawa caryophyllene dan germacrene $D^{17}$. Jalur antioksidan dan antiinflamasi ini menyebabkan kerusakan hepar yang dihasilkan oleh rifampisin dapat diminimalisir.

Meskipun pada antar kelompok P1, P2, dan P3 mengalami penurunan yang signifikan $(\mathrm{p}<0.05)$ tetapi pada kelompok P3 terjadi peningkatan yang signifikan $(\mathrm{p}<0.05)$ sebesar $6 \%$ dibandingkan dengan kelompok $\mathrm{P} 2$. Hal ini diduga tejadi karena tingginya kadar bahan aktif dalam minyak atsiri daun sirsak (Annona muricata Linn.) dapat merubah sifat dari antioksidan menjadi prooksidan ${ }^{18}$. Kondisi ini menyebabkan pada pemberian dosis minyak atsiri sebesar $6 \%$ cenderung terjadi penurunan efek. Untuk itu diperlukan penelitian lanjutan mengenai dosis toksik untuk minyak atsiri daun sirsak (Annona muricata Linn.) agar pemanfaatannya lebih optimal.

\section{KESIMPULAN}

Berdasarkan hasil analisis data dan pembahasan dalam penelitian ini, dapat disimpulkan bahwa:

1. Pemberian induksi rifampisin dosis 10 $\mathrm{mg} / \mathrm{kgBB}$ selama 6 minggu dapat meningkatkan kadar TNF- $\alpha$ hepar tikus wistar yang menunjukkan adanya kerusakan pada hepar.

2. Pemberian minyak atsiri daun sirsak (Annona muricata Linn.) dosis 1,5\%, 3\%, dan $6 \%$ mampu menurunkan kadar TNF- $\alpha$ hepar tikus wistar yang diinduksi rifampisin. Namun terdapat kecenderungan peningkatan dosis akan meningkatkan kadar TNF- $\alpha$ yaitu pada dosis $6 \%$.

3. Pemberian minyak atsiri daun sirsak (Annona muricata Linn.) dosis 3\% merupakan dosis optimal untuk menurunkan kadar TNF- $\alpha$ hepar tikus wistar yang diinduksi rifampisin.

\section{SARAN}

Berdasarkan hasil penelitian yang telah dilakukan, guna peningkatan dan pengembangan lebih lanjut peneliti menyarankan:

1. Perlu dilakukannya uji toksisitas dari minyak atsiri daun sirsak (Annona muricata Linn.) pada hewan coba tikus wistar jantan untuk mengetahui dosis optimal.

2. Perlu dilakukan molecular docking untuk mengetahui mekanisme kerja minyak atsiri daun sirsak.

\section{UCAPAN TERIMA KASIH}

Terima kasih disampaikan kepada semua pihak yang telah membantu dan memfasilitasi pelaksanaan penelitian ini.

\section{DAFTAR PUSTAKA}

1. Katzung, Bertram G. Farmakologi Dasar \& Klinik edisi 12 hal.951-952. Jakarta : EGC. 2013.

2. Kishore, P.V., et al. Drug Induced Hepatitis with Anti-tubercular Chemotherapy: Challenges and Difficulties in Treatment, Kathmandu University Medical Journal, Vol. 5, No. 2, Issue 18, 256-260. 2007.

3. Holt, Michael, P., and Cynthia, Ju. Mechanisms of Drug-Induced Liver Injury. Department of Pharmaceutical Sciences, School of Pharmacy, University 
of Colorado Health Sciences Center, 4200 E 9th Ave, Box C-238, Denver, CO 80262. 2006.

4. Baratawidjaja, Karnen Garna dan Rengganis, Iris. Imunologi Dasar. Edisi 9. Jakarta: Balai Penerbit FK-UI. 2010.

5. Sudarjanto. Manfaat Sirsak. http://sudarjanto.multiply.com/journal/item /6695. Diakses tanggal 22 November 2015. 2010.

6. Adewole, S.O., and Ojewole, J.A.O. Protective effects of Annona muricata linn. (Annonaceae) leaf aqueous extract on serum lipid profiles and oxidative stress in hepatocytes of Streptozotocin-treated diabetic rats, Afr. J. Trad.Cam., 6 (1), 30 41. 2009.

7. Nahdhiyah, U. Efek Perasan Buah dan Rebusan Daun Sirsak (Annona muricata Linn.) terhadap Kadar SOD Jaringan Hepar Tikus Wistar yang Diinduksi Rifampisin. Program Pendidikan Dokter Fakultas Kedokteran Universitas Islam Malang. 2012.

8. Damayanti, Dini Sri. Potensi Minyak Atsiri Daun Sirsak (Annona muricata Linn.) sebagai Antioksidan melalui Penghambatan DPPH secara In Vitro dan Efek terhadap Peningkatan HSP70 Hepar Tikus Wistar Jantan yang Diinduksi Rifampisin. Laporan Penelitian Dosen Fakultas Kedokteran Universitas Malang. Malang. 2016.

9. Notoadmodjo, S. Metodologi penelitian kesehatan. Jakarta: PT. Rineka Cipta. 2002.

10. Subekti, N.K. Uji Toksisitas Akut Ekstrak Metanol Daun Laban Abang (Aglalia elliptica BLUME) terhadap Larva Udang (Artemia salina LEACH) dengan Metode Brine Shrimp Lethality Test (BSLT). Fakultas Kedokteran dan Ilmu Kesehatan Universitas Islam Negri Syarif Hidayatullah. Jakarta. 2014.

11. Crowther, J.R. The ELISA Guide Book Methods in Molecular Biology. The International Atomic Energy Agency. Vienna. Austria. Humana Press Inc Totawa, New Jersey. 2001.

12. Jannah, L.N. Efek Minyak Atsiri Daun Sirsak (Annona muricata Linn.) terhadap Jumlah Nekrosis Sel Hepatosit dan Volume Hepar Tikus Wistar Jantan yang Diinduksi Rifampisin. Skripsi. Fakultas Kedokteran Universitas Malang. Malang. 2016.

13. Chen, J., dan Raymond, K. Roles of Rifampicin in Drug-Drug Interactions: Underlying Molecular Mechanisms
Involving The Nuclear Pregnane $X$ receptpr, Annals of Clinical Microbiology and Antimicrobia; 5:1-11. 2006.

14. Schneider, C.D., Alvaro, R.O. Oxygen Free Radicals and Exercise:Mechanism of Synthesis and Application to the Physical Training. Rev Bras Mod Esporte Vol:10 No.4. 2004.

15. Mahdi, Chanif. Efek Paparan Formaldehid dan Suplementasi Yogurt terhadap Aktivitas Antioksidan Kerusakan Oksidatif, Profil dan Karakter Protein Jaringan Hepar Tikus (Rattus norvegicus). Malang: Ringkasan Disertasi Program Studi Ilmu Kedokteran Kekhususan Biomedik, Program Pascasarjana Universitas Brawijaya. 2008.

16. Kumar, V., Cotran, R.S., Robbins, S.L. Buku Ajar Patologi Robbins, Volume 2, Ed. 7. EGC. Jakarta. 2007.

17. Miguel, Maria Graca. Antioxidant and Anti-inflamatory Activities of Essential Oils:A Short Review. Molecules;15:92529287. 2010.

18. Prochazkova, D., Bousova, I., Wilhelmova, N. Antioxidant and Prooxidant Properties of Flavonoids. Elsevier. Fitoterapia 82;513-523. 2011. 